\title{
WATER RESOURCE MANAGEMENT IN MALAYSIA: LEGAL ISSUES AND CHALLENGES
}

\author{
S.A. RAHMAN ${ }^{1} \&$ R.M. KHALID ${ }^{2}$ \\ ${ }^{1}$ Faculty of Economics and Management, Universiti Putra Malaysia, Malaysia. \\ ${ }^{2}$ Faculty of Law, Universiti Teknologi MARA, Malaysia.
}

\begin{abstract}
The two-wave flood incident in Malaysia in 2006 has raised concerns over the economical, sociological and psychological impact on the victims. Nevertheless, many do not realize that the tragedy has been exacerbated due to the current structure of water resource management system in the country. This paper discusses the complexities of the present legal framework with regard to water resource management in Malaysia. An examination has been made to the current Federal Constitution as well as the Federal legislations. The study proves that the problem related to water resource management in Malaysia is partly due to the unclear division of power between the Federal and the State Governments and the fragmented legislation on Malaysian water.

Keywords: sustainable development, water laws, water resource management.
\end{abstract}

\section{INTRODUCTION}

As a developing nation, Malaysia has been experiencing rapid urbanization and development. High-rise commercial buildings have become common and the number of housing estates is rising at an unimaginable rate. These developments do come with some prices. Many of its tropical rainforests, which act as its natural storm water preservation, have been cleared to make way for development. Most of the flood storage has been reduced due to developments extending into and taking over flood plains and the drainage corridor. As a result, many cities in Malaysia like its capital Kuala Lumpur and cities in industralized states like Selangor, Penang and Johore often experience occasional flooding. Although the global change in climate may have contributed to the situation, the inefficient water resource management in the country does play some part in it. This paper aims to look at the existing legal framework of water resource management in the country and identifies problems that may hinder improvement in its water resource management.

\section{THE CONSTITUTIONAL FRAMEWORK FOR WATER RESOURCE MANAGEMENT} IN MALAYSIA

Malaysia is a federation of 13 states and three federal territories. The Federal Constitution clearly indicates that water is a state matter, and this includes rivers, lakes, streams and groundwater. This, however, is not exclusive as under the Federal List of the Constitution, the Federal Government has power over certain water-based projects in the state, such as hydropower generation, navigation within ports, marine fisheries and mining. In addition, drainage and irrigation has been stipulated under the Concurrent List, and hence fall under the jurisdiction of both Federal and State Governments. Under Article 76 of the Constitution, the Federal Government has the power to enact any law under the State List for the purpose of achieving uniformity, in compliance with an international treaty, or simply at the request of the state. Nevertheless, these regulations will not be effective unless the State Legislature approves them [1].

The Federal Constitution has recently been amended in 2005 to delete the item "water supply and services' from the State List and insert it in the Concurrent List. This will enable the Federal Government's involvement in the water services sector and to establish a regulated water services industry. Prior to the amendment, State Governments have established different types of water supply organizations, some fully privatized and some for operation and maintenance. Since privatization

(C) 2009 WIT Press, www.witpress.com

ISSN: 1743-7601 (paper format), ISSN: 1743-761X (online), http://journals.witpress.com DOI: $10.2495 / \mathrm{SDP}-\mathrm{V} 4-\mathrm{N} 3-258-264$ 
was done through concession agreements that vary from state to state, some states have been ended up in high non-revenue water [2]. The lack of adequate financial resources in the states has led to deterioration in the quality of services provided. The amendment was thus made to eradicate these problems.

In 2004, after the cabinet reshuffle, three ministries share water-related responsibilities. They were divided under three components - water for environment, water for food and water for people. The Ministry of Energy, Water and Communication [3] will be the guardian of water for people. It shall improve the water supply services, previously under the Ministry of Works, and organize sewerage work, formerly under the responsibilities of the Ministry of Housing and Local Government. Water service requirement for agriculture and food remains with the Ministry of Agriculture and Agro-Based Industry. Finally, the Ministry of Natural Resources and Environment is tasked to take charge over water for environment. In this regard, its Department of Irrigation and Drainage will be responsible for flood defence, drainage and irrigation, while the Department of Environment is to control water pollution. The Ministry has also created a research department called the National Hydraulic Research Institute of Malaysia or NAHRIM [4] to conduct research and development in the water industry.

\section{LEGAL ISSUES UNDER THE FRAMEWORK}

\subsection{Constitutional conflict}

It is clear that the State Governments will have exclusive jurisdiction over the management of water resources like water catchment areas and ground water. In fact, matters related to rivers, land and forest remain under the exclusive jurisdiction of the state. Nevertheless, as the Federal Government has power over water-based projects in the state, from time to time, it has been formulating policies that will be implemented at the state level. This is sometimes made with little support from the State Governments. For instance, when the Federal Government initiates the need to gazette certain catchments areas within certain states, the State Governments have shown some reluctance as most of their incomes come from logging and industrial activities that operate in those designated areas. The 2005 Constitutional Amendment has indicated the Federal Government's intention to manage the water sector in the country. Although it aims to make the water service industry uniform, it can be interpreted as another encroachment by the Federal Government into state's authority over water and to some extent de-federalizing the water resource management in Malaysia.

\subsection{Duplication of departmental authority}

Water resources management is divided into sectors within various government departments, both at the federal and state level. To begin with, the Water Supply Department under the local authorities will manage the water supply while irrigation and drainage is managed by the Department of Irrigation and Drainage. However, the Public Works Department will be in charge of the roadside drain if the roads fall under its jurisdiction. Similar crowd can be seen in the case of land development. If it is closely related to water resource management for sustainable development, the authority shall be the Town and Country Planning Department. Nevertheless, the task of enforcing water quality and producing drainage regulations are shared between the Department of Environment and the Department of Local Government. With so many agencies focusing on different but limited aspects of water resources management, there are gaps and overlaps in their jurisdictions which complicate their task [5]. 


\subsection{Lack of manpower}

With regard to flood mitigation and control, most local authorities produce by-laws that compel land developers to construct connecting drains to the nearest point of discharge. They also make final decisions for planning proposals that include layout and drain reserves for storm water drainage. These duties may to some extent help them in monitoring development in the urban area so as not to contribute to flooding as a result of increasing runoff rates. Be that as it may, many local authorities are inadequately staffed especially in monitoring and enforcement. For storm drainage and technical matters, they often rely on the advice from the Department of Irrigation and Drainage. In the true spirit of inter-departmental cooperation, the Department often goes beyond merely giving advice, as in some cases it prepares the drainage master plans or build some of the trunk drainage network for the local authorities [6]. The local authorities are also relying on the Town and Country Planning Department who will prepare structural plans and sometimes local plans when they are facing staff shortages. While inter-departmental cooperation is important, being too dependent is neither healthy nor does it solve the main problem.

\subsection{Financial constraint}

The local authority is generally responsible for the design and construction of urban storm drainage facilities. However, effective storm water management facilities require large funding. In Malaysia, due to the three-tier structure of the Federation, i.e. the federal, the state and the local authority, and for the sake of efficient services, many of the functions such as supply of water, and even public transportation, have been outsourced under privatization. As a result, local authorities have limited income that come from drainage fee, licensing fee or car park revenues. In many occasions, funds can be obtained from financial institutions, whereby the Federal Government acts as the guarantor, or from the federal grants and loans. The limited resources may also hinder the authority from implementing or providing subsidies or rebates to the general public for installing water efficient or water saving equipments like the local authorities in Australia or Japan.

\subsection{Fragmented legislations}

To date, the Federal Government has enacted several water-related laws that started as early as the Waters Act 1920 (Revised 1989). This is followed by the Street, Drainage and Building Act 1974, the Town and Country Planning Act 1976, the Local Government Act 1976 and the Environmental Quality Act 1974. After the 2005 constitutional amendment, another two Acts of Parliament were passed, namely the Water Services Industry Act 2005 and the National Water Services Commission Act 2005. Each of these acts is governed by a particular ministry or agency. All of this inevitably created gaps and overlaps in the responsibilities for managing water resources.

\section{REFORMS IN WATER RESOURCE MANAGEMENT IN MALAYSIA}

\subsection{Capacity building}

Based on the above, despite the fact that water is a state matter and it is up to the local authorities to manage and implement, they have certain problems, ranging from money to manpower, in performing their duties. It is the responsibility of both Federal and State Governments to equip them with enough funds and personnel for efficient implementation. In the Ninth Malaysia Plan (2006-2010), human 
resources development has been given the largest budget allocation, which will enhance the performance of personnel in the water industry.

\subsection{Integrated Water Resource Management}

Integrated Water Resource Management (IWRM) is considered as a best tool to improve the current fragmented approach over water resource management system in Malaysia. It is a process that promotes the coordinated development and management of water and related resources to maximize the economic and social welfare in an equitable manner without compromising the sustainability of the ecosystem [7]. IWRM was actually introduced in the country by the Department of Irrigation and Drainage in the 1990s. In 1997, the Malaysian Water Partnership was formed, it included various players in the water industry to promote IWRM in Malaysia. After the 2005 Bali Forum that launched the 'UNEP Support for Achieving the IWRM 2005 Target', NAHRIM is tasked to implement IWRM. To date, it has initiated several projects to create awareness and generate advocacy in IWRM throughout Malaysia [8].

\subsection{Institutional reform}

The year 2004 has witnessed a major overhaul in the water service sector in the country. Eleven departments from four ministries were combined in the Ministry of Natural Resources and Environment. As discussed above, three Ministries will share the responsibilities to legislate on water-related matters. State Governments are also encouraged to enact specific water resources management legislations that ensure integrated management over water industry. To date, the State of Selangor has taken initiative towards managing water for sustainable development. It has established the Selangor Waters Management Authority in 2000 to improve the management of water catchments within its four local authorities.

\subsection{Flood mitigation programme}

Although changes in climate trigger flood, rapid urbanization and industrialization in the country can also contribute to flooding if systematic and adequate drainage system are not put into place. In this regard, the Drainage and Flood Mitigation Division of the Department of Irrigation and Drainage (DID) is responsible for formulating Flood Mitigation Program throughout the country and managing several major Flood Mitigation Projects at the major rivers like Sungai Muda and Sungai Perai.

Another improvement made by the Department is the Stormwater Management and Road Tunnel project to mitigate flooding in the capital city of Kuala Lumpur (Fig. 1). Initially, it is a stormwater management system that diverts excess stormwater away from the catchments at the downstream of Sungai Ampang and Sungai Klang to an underground holding pond, a bypass tunnel and a storage reservoir before releasing it back to the catchment area. However, during the design stage, the dual-purpose concept was born from the ingenuity of the project proponents and the motorway tunnel was integrated into the system to relieve traffic congestion at the main Southern Gateway to the city centre [9]. Thus, it provides both smart and magic answer to all residents in Kuala Lumpur who are faced with daily congestion and occasional flash flood.

The Department itself has produced the Urban Stormwater Management Manual in 2000. The Manual is only a guideline, but the Ministry of Natural Resources and Environment is considering making it a law for better implementation [10]. The Manual introduces the control at source concept through the construction of swale, detention and retention ponds in the new development schemes to 


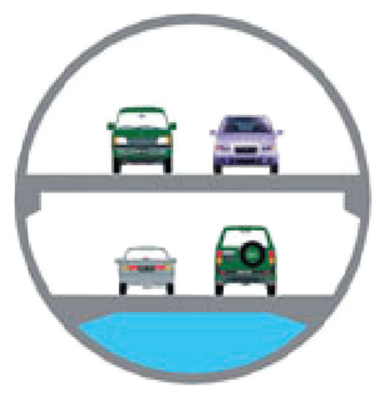

Figure 1: Stormwater Management and Road Tunnel.

hold the runoff from going directly into the waterways. The Department, however, noted that for it to succeed, it would require planning and implementation that is consistent throughout the local, state and federal administrations to ensure that all of its objectives are met. The state's Economy Planning Unit will have to carry out overall policy coordination. To this end, state's development planning policies, Integrated River Basin Management Plans, implementation strategies and institutional reforms should be consistent among all states.

\subsection{Rainwater harvesting}

Rainwater harvesting or rainwater utilization has the potential to solve two water problems in Malaysia, i.e. shortage of water and excess of water. If implemented, it shall reduce the national demand for water supply as well as alleviate flood risks by easing flows into the stormwater management grid. The government initiated the idea after the 1998 drought in Kuala Lumpur. To date, NAHRIM and DID have started several rainwater harvesting pilot projects around the country. Rainwater harvesting has been included in the National Urbanization Policy 18 produced by the Town and Country Planning Department [11]. The Ministry of Communication, Water and Technology has also been campaigning for water saving through rainwater harvesting. Despite all the efforts, progress is still slow. On 27 March 2007, the Federal Government announced that rainwater harvesting would be made mandatory to large buildings in the country [12]. The Ministry of Housing and Local Government is tasked to develop new by-laws for compulsory rainwater harvesting and is expected to present it in late 2008. This is certainly a good start for a more sustainable development in this country.

\section{FURTHER CHALLENGES TOWARDS IWRM IN MALAYSIA}

\subsection{Dawdling progress towards IWRM}

The water resource management in Malaysia has been sectoral and fragmented for decades. Although various programmes have been developed to create awareness for IWRM, there is still a general lack of understanding of IWRM and hence the development towards it has been very slow. Thus, there is an urgent need to make progress in streamlining the individual sectorial policies. By doing this, it will help each department to achieve their goals and they can identify any gaps in the implementation and enforcement. NAHRIM has organized several workshops for that purpose. In this regard, it might use the 'Strategic Planning and Management (SPM) Tools for IWRM' [13], which require changes 
in the key stakeholders' thinking. Here, capacity building is essential and part of the process for successful implementation.

\subsection{Financial implication}

IWRM requires each department to consider and integrate the costs in other departments affected by any projects proposed by a department. Streamlining departments' policies, however, may lead to increased budgetary request from other affected departments. This can be seen in the relationship between land use and development sector. Here, issues like planning, urban drainage, water pollution and water quality involves several departments and each has its own budget implication [14]. It is submitted that by streamlining the key IWRM departments, they shall identify the total cost paradigm, which in the long run can ensure sustainability and the cost effectiveness of such projects.

\subsection{Federal-State conflict}

The Federal Government's efforts to uniform the water laws, especially in the case of IWRM, are often hampered by the states which prefer to stick to their state legislations because of tradition. Some states like Sabah and Sarawak have more advanced legislation due to both historical and constitutional factors, and this may further hinder the Federal Government's initiatives. The most effective way to solve this problem is through continuous negotiation between them. Both parties will need to discuss and improve coordination process when matters fall within both jurisdictions. Each party's role and responsibilities will also need to be clearly defined. This is vital as failure to achieve consensus on environmental matters may lead to unsustainable development in the future.

\subsection{Social attitude}

The overall effectiveness of IWRM depends more on the mind set of the politicians as well as the general public. In this regard, Malaysian society needs to understand the issues surrounding the water sector and play their parts in ensuring a more sustainable future. As a general public, they can support it by simply using water wisely. The utilization of rainwater may not only reduce dependency on piped water but also, if practiced at a macro level, eliminate occasional flood. The government needs to ensure stakeholder participation in the decision-making process. Creating the water sector database [15] for easy dissemination of knowledge can help in creating awareness among relevant stakeholder and the general public. The voice of the people will no doubt act as an impetus to translate the awareness into political will and capacity.

\section{CONCLUSIONS}

As a result of rapid urbanization, water problems such as flood cannot be seen as a localized issue, but as a national issue. To this end, the Federal Government has started a few plans to identify and reduce the causes and to provide solutions if it occurs. Nevertheless, it is the integration, and not conflict, which has to be maintained between related government departments to achieve a successful water resource management in this country. This, however, requires a great deal of cooperation and financial provision. Cooperation can only be achieved if government departments understand their scope of authority. A move by the Federal Government to create two new ministries to deal with water management indicates the Federal Government's intention to coordinate the water management that previously varied between states. This should not be seen as an encroachment into state's jurisdiction but rather as a helping hand. Furthermore, state governments cannot afford the cost of implementing 
a sustainable and integrated water resource management without full support from the Federal Government. Thus, they need to cooperate in planning and managing water as failure would lead to frequent occurrence of water shortage or flood in the future.

\section{REFERENCES}

[1] Article 78 of the Federal Constitution, http://www.malaysia-today.net/malaysia_constitution.pdf (accessed May 25, 2008).

[2] Raja Zainal Abidin, R.Z., Water services agenda in the ninth plan. Water Malaysia, (10), pp. 11-13, 2005.

[3] www.ktak.gov.my (accessed March 30, 2007).

[4] www.nre.gov.my, www.doe.gov.my, www.nahrim.gov.my (accessed March 30, 2007).

[5] Abdullah, K., Water for a sustainable development towards a developed nation by 2020. Proceedings of the National Conference on Water for a Sustainable Development towards a Developed Nation by 2020, pp. 1-7, 2006; see also www.kpkt.gov.my, www.townplan.gov.my (accessed March 30, 2007).

[6] Urban Stormwater Management Manual, Department of Irrigation and Drainage, Kuala Lumpur, para 5-2 /5-3, 2000, or http://www.water.gov.my/index.php?option=com_content\&task=view \&id=188\&Itemid=564 (accessed May 25, 2008).

[7] Global Water Partnership, Integrated Water Resource Management. Stockholm, Sweden Background Paper No. 4, 2000.

[8] IWRM 2005 Report for Malaysia, NAHRIM, September, p. 15, 2006.

[9] http://www.smarttunnel.com.my/project_help.htm (accessed March 11, 2007).

[10] http://www.bernama.com.my/bernama/v3/bm/printable.php?id=230435 (accessed January 18, 2007).

[11] National Urbanization Policy, Town and Country Planning Department, Kuala Lumpur, p. 78, 2006, or www.townplan.gov.my/dpn (accessed May 25, 2008).

[12] http://www.thestar.com.my/news/story.asp?file=/2007/3/28/nation/17271769\&sec=nation\&=1 (accessed March 28, 2007).

[13] Jezeph, D., Strategic planning and management (SPM) tools for IWRM. NABRO, 29 July 2004.

[14] IWRM 2005 Report for Malaysia, NAHRIM, September, p. 21, 2006.

[15] 'Malaysia's Water Vision: The Way Forward', http://www.fao.org/DOCREP/004/AB776E/ ab776e02.htm (accessed December 24, 2007). 